\title{
Association between the second-to-fourth digit (2D:4D) ratio and myopia in medical students of the Medical Faculty of the Jenderal Soedirman University
}

Dzicky Rifqi Fuady', Fitranto Arjadi ${ }^{1}$, Joko Mulyanto², Lantip Rujito³, M. Rifqy Setyanto 4

'Department of Anatomy, Faculty of Medicine, Jenderal Soedirman University, Purwokerto, Indonesia; ${ }^{2}$ Department of Public Health, Faculty of Medicine, Jenderal Soedirman University, Purwokerto, Indonesia; ${ }^{2}$ Department of Molecular Biology, Faculty of Medicine, Jenderal Soedirman University, Purwokerto, Indonesia; ${ }^{4}$ Department of Ophthalmology, Faculty of Medicine, Jenderal Soedirman University, Purwokerto, Indonesia

\begin{abstract}
Refractive error is one of the biggest eye problems in young people. The most prevalent refractive error, myopia, is continuously increasing. The myopia degree impact results in serious complications in the eye. Current studies report that myopia is associated with the genetic and hormonal system. The second-to-fourth digit (2D:4D) ratio on the other hand, has been reported as being related to the genetic and hormonal mechanism. This study aimed to establish an association between the 2D:4D ratio and myopia cases in medical students of the Medical Faculty of Jenderal Soedirman University. This was a quantitative observational analytic research with a cross-sectional approach. One hundred students, divided into a myopia group and an emmetropia group, were recruited for the study. Digit measurement was done using a computer-based method by two independent observers, whereas an eye refraction test was conducted by an independent refractionist. An independent $t$-test on the 2D:4D ratio showed no difference in values $(p>0.05)$ between the myopia group and the emmetropia group. In conclusion, the study reported that there was no significant association between the 2D:4D ratio with myopia cases in medical students of Medical Faculty of Jenderal Soedirman University.
\end{abstract}

Keywords: Myopia, 2D:4D ratio, Jenderal Soedirman

\section{Introduction}

Myopia makes up 54\% of total eye problems and is the most frequent refractive error in the world. WHO found that myopia prevalence is $43 \%$ of the total world population. ${ }^{1}$ Myopia prevalence is higher in the South-East Asia region. ${ }^{2}$ The last report showed that the prevalence in Vietnam, Singapore and Indonesia was $20.4 \%,{ }^{3} 32.4 \%{ }^{4}$ and $3.69 \%,{ }^{5}$ respectively.

Myopia needs immediate recognition and prevention to avoid dangerous complications. High-grade myopia of more than S -6.0 diopter, especially high-grade axial

Correspondence: Dzicky Rifqi Fuady, Department of Anatomy, Faculty of Medicine, Jendral Soedirman University, J. Dr Gumbreg No 1 Mersi Purwokerto 53122.

E-mail: dzicky.rifai.fuady@gmail.com. 
myopia, can increase the risk for serious complications such as cataract, glaucoma, retinal ablation, chorioretinal atrophy, and lacquer cracks in the retina. ${ }^{6}$ Elongation of the axial length can stretch the choroid and retinal epithelium, leading to complications. ${ }^{7}$ Myopia can lead to blindness, being the number-seven cause of blindness. ${ }^{8} \mathrm{High}$-grade untreated myopia also can decrease the quality of life based on eye complication and discomfort because of the use of eyeglasses., ${ }^{90,12}$

Myopia can be progressive. In China, a study found that the degree of myopia can increase up to $S(-0.6)-(-0.7)$ diopter each year whereas in Singapore, a report said the increment was $\mathrm{S}-2.4$ diopter every three years. ${ }^{6,11}$

Myopia is associated with genetic and hormonal factors. Prenatal androgen exposure at 13 weeks of gestation has an effect on axial length and myopia progression. The sexual steroid hormone can also alter corneal thickness and corneal curvature. ${ }^{13}$ Genetically, MYP and Homeobox (HOX) gen can also alter scleral thickness and corneal curvature. ${ }^{14}$ Those alterations in corneal thickness and curvature can lead to myopia. ${ }^{15}$ SMOC1 gene can also induce bone morphogenic pathway (BMP) intrauterine to regulate eye axial length and appendicular skeleton development. ${ }^{16}$

Second-fourth digit ratio (2D:4D ratio) is measured by dividing the second digit length with the fourth digit ratio. Digit length is measured from the first line in basal crease line which reflects the base of metacarpophalangeal joints. ${ }^{34} 2 \mathrm{D}: 4 \mathrm{D}$ ratio is also associated with genetic and hormonal factors. Hormonally, androgen exposure in week 13 of gestation makes the fourth digit longer, so the 2D:4D ratio is lower. Androgen exposure is higher in males, so the 2D:4D ratio in males is lower than in females. ${ }^{17}$ An adult male has 0,98 of mean 2D:4D ratio, which is lower than adult female, with one of mean $2 \mathrm{D}: 4 \mathrm{D}$ ratio. ${ }^{17}$ Females with congenital androgen hyperplasia have higher androgen levels and tend to have lower 2D:4D ratio and males with Kinefelter syndrome have higher 2D:4D ratio. ${ }^{18,19}$

Genetically, the 2D:4D ratio is associated with HOX gene and Androgen Receptor (AR) gene. HOX gene regulates anterior-posterior axis, including digit length and eye axial length, and it also regulates segmentation of body during embryonal development. ${ }^{20}$ Androgen hormone can also induce SMOC1 gene and HOX gene, which impacts appendicular skeleton and digit development. ${ }^{16}$ CAG sequence repeats in AR gene have minimal effect on 2D:4D ratio and is still debated. The number of CAG sequence repeat in AR gene has reduced effects on androgen level so the $2 \mathrm{D}: 4 \mathrm{D}$ ratio is higher. ${ }^{22}$

This research was conducted to observe association between 2D:4D with myopia cases in medical students of the Medical Faculty of Jenderal Soedirman University. The current hypothesis about the association between 2D:4D ratio and myopia so far was mainly because of the effect of prenatal androgen steroid exposure. Prenatal androgen exposure impacts HOX gene in regulating digit length and 2D:4D ratio. It also impacts scleral tissue proliferation which alters axial length and progressing into axial myopia. ${ }^{16}$ Recent research conducted by Krishnakumar et al., (2014) shows that there was significant association between 2D:4D ratio and myopia in a female group, and the rest remains insignificant. ${ }^{16}$ 


\section{Method}

\section{Study Design}

This study was a quantitative observational analytical research with cross-sectional study design. Ethic certificate was received from ethical commission of Medical Faculty Jenderal Soedirman University.

\section{Participants}

The participants in this study were 100 students from the Medical Faculty of Jenderal Soedirman University. Complete randomized design was adopted to receive proportional to size (PPS) sampling. Inclusion criteria were: no hand anatomical congenital deformities and anomaly, no destructive hand trauma history, no joints disease history, body mass index (BMI) $18,5-23 \mathrm{~kg} / \mathrm{m}^{2}, 19-21$ years of age, in both the myopia and emmetropia group. Astigmatism, no responses, and no better correction (NBC) or no correction (NC) refraction status were set as exclusion criteria.

\section{Data sources and settings}

Digit length was measured by a computer-based method. Participants' right and left hand were scanned using Canon ${ }^{\oplus}$ CanoScan LiDE 120 (Vietnam). The measurement value was counted using a measurement tool on Adobe ${ }^{\circledast}$ Photoshop ${ }^{\circledR}$ CS6 in pixel(s) unit. Measurement was taken in Computer Laboratory in the Faculty of Medicine Jendral Soedirman University.

An independent refractionist conducted refraction tests using a standard trial lens, trial frame and also automatic Snellen chart projector. Myopia degree was stated in spherical negative (S-) diopters and presented in numerical value. The test was done in the Public Eye Center (Balai Kesehatan Mata Masyarakat) Purwokerto. In order to avoid measurement bias, digit length measurement was executed by two observers.

\section{Statistical analysis}

Univariate analysis consisted of mean and standard deviation of respondent age, body mass index (BMI), and myopia degree. Independent t-test used to observe 2D:4D ratio difference between myopic and emmetropic respondent. Pearson test and Spearman test were used to observe correlation between myopia degrees and 2D:4D ratio. The Spearman test was used in the total myopic and the female group, whereas Pearson test was used in the male group and used to check inter-observer correlation.

\section{Result}

\section{Participants}

The total population of students in the Medical Faculty Jenderal Soedirman University was screened using a questionnaire to get basic characteristics of respondents and temporary subjective eye refractive conditions, whether it was emmetropia, myopia, or astigmatism. 


\section{Basic respondent characteristics}

Age and $\mathrm{BMI}$ were controlled variables, so the range is still on the controlled range, $19-21$ years old and $18.5-23 \mathrm{~kg} / \mathrm{m}^{2}$ for BMI. In gender data, the female respondents (82 students) outnumbered the male respondents (18 students). Myopia degree for right and left eye for myopic respondents was summarized in the range of $\mathrm{S}-(2.00$ \pm 1.50 ) diopter (Table 1).

Table 1. Descriptive data of participants.

\begin{tabular}{|c|c|c|}
\hline Characteristics & Group & \\
\hline & $\begin{array}{l}\text { Myopia } \\
n=47\end{array}$ & $\begin{array}{l}\text { Emmetropia } \\
n=53\end{array}$ \\
\hline Age & $19.96 \pm 0.86$ & $19.91 \pm 0.766$ \\
\hline BMI & $20.75 \pm 1.36$ & $20.73 \pm 1.38$ \\
\hline \multicolumn{3}{|l|}{ Gender } \\
\hline Male & $\begin{array}{l}7 \\
(38.9 \%)\end{array}$ & $\begin{array}{l}11 \\
(61.1 \%)\end{array}$ \\
\hline Female & $\begin{array}{l}40 \\
(48.8 \%)\end{array}$ & $\begin{array}{l}42 \\
(51.2 \%)\end{array}$ \\
\hline $\begin{array}{l}\text { Mean right eye myopia degree } \\
\text { (S -diopter) }\end{array}$ & $2.00 \pm 1.55$ & - \\
\hline $\begin{array}{l}\text { Mean left eye myopia degree } \\
\text { (S -diopter) }\end{array}$ & $1.95 \pm 1.54$ & - \\
\hline $\begin{array}{l}\text { Low-grade myopia respondent } \\
\text { (S -0.25 till S -3 diopter) }\end{array}$ & $\begin{array}{l}33 \\
(66 \%)\end{array}$ & - \\
\hline $\begin{array}{l}\text { Moderate-grade myopia respondent } \\
\text { (S -3 till S -6 diopter) }\end{array}$ & $\begin{array}{l}16 \\
(32 \%)\end{array}$ & - \\
\hline $\begin{array}{l}\text { High-grade myopia respondent } \\
\text { (> S-6 diopter) }\end{array}$ & $\begin{array}{l}1 \\
(2 \%)\end{array}$ & - \\
\hline
\end{tabular}

Digit measurement characteristics

Calculation of 2D:4D ratio found that mean 2D:4D ratio was between 0.96-0.97. A Pearson correlation test was used to analyze inter-observer measurement correlation and the result was a significant $(p<0.05)$ and very strong $(r>0.8)$ correlation between the two observers (Table 2). 
Table 2. The characteristics of digit measurement result.

\begin{tabular}{|c|c|c|c|c|}
\hline Characteristics & $\begin{array}{l}\text { Measurement } \\
\text { result }\end{array}$ & $\begin{array}{l}\text { Inter-observer } \\
\text { correlation }\end{array}$ & & \\
\hline & & $\mathbf{R}$ & $\mathbf{P}$ & \\
\hline \multirow[t]{2}{*}{ Right hand (pixel(s)) } & $2^{\text {nd }}$ digit & $822.99 \pm 51.12$ & 0.984 & $0.000^{* *}$ \\
\hline & $4^{\text {th }}$ digit & $847.00 \pm 55.94$ & 0.970 & $0.000^{* *}$ \\
\hline \multirow[t]{2}{*}{ Left hand (pixel(s)) } & $2^{\text {nd }}$ digit & $818.00 \pm 51.39$ & 0.985 & $0.000^{* *}$ \\
\hline & $4^{\text {th }}$ digit & $846.64 \pm 55.34$ & 0.980 & $0.000^{* *}$ \\
\hline \multirow[t]{3}{*}{ 2D:4D ratio } & Right hand & $0.972 \pm 0.028$ & 0.914 & $0.000^{* *}$ \\
\hline & Left hand & $0.967 \pm 0.030$ & 0.955 & $0.000^{* *}$ \\
\hline & Mean & $0.969 \pm 0.026$ & 0.950 & $0.000^{* *}$ \\
\hline
\end{tabular}

**Significant $(p<0.01)$

\section{Association between 2D:4D ratio and myopia cases}

Observation of association between 2D:4D ratio and myopia cases was done using $t$-independent test. This analysis discovered that there was no significant $(p>0.05)$ 2D:4D ratio difference between myopia and emmetropia respondents. Table 3 also shows us that in the total sample female group, the 2D:4D ratio was higher in myopic respondents than emmetropic respondents in the male group, $2 \mathrm{D}: 4 \mathrm{D}$ ratio in myopic respondents is lower than in emmetropic respondents. We could also notice that males had lower 2D:4D ratio than females.

Table 3. The result of t-independent test to observe association between 2D:4D ratio and myopia cases.

\begin{tabular}{|l|l|l|l|l|}
\hline Group & Object & $\begin{array}{l}\text { Myopia } \\
(\mathbf{n = 4 7})\end{array}$ & $\begin{array}{l}\text { Emmetropia } \\
(\mathbf{n = 5 3})\end{array}$ & $p$ value \\
\hline Total sample $(\mathbf{n}=\mathbf{1 0 0})$ & Right hand & $\mathbf{0 , 9 7 4 \pm 0 , 0 2 7}$ & $0,970 \pm 0,029$ & 0,450 \\
\hline & Left hand & $0,969 \pm 0,032$ & $0,965 \pm 0,029$ & 0,504 \\
\hline & Mean & $0,972 \pm 0,026$ & $0,968 \pm 0,027$ & 0,436 \\
\hline Male $(\mathbf{n = 1 8 )}$ & Right hand & $0,952 \pm 0,016$ & $0,968 \pm 0,034$ & 0,249 \\
\hline & Left hand & $0,946 \pm 0,018$ & $0,965 \pm 0,031$ & 0,176 \\
\hline & Mean & $0,949 \pm 0,014$ & $0,967 \pm 0,031$ & 0,187 \\
\hline Female $(\mathbf{n}=\mathbf{8 2})$ & Right hand & $0,978 \pm 0,026$ & $0,971 \pm 0,028$ & 0,203 \\
\hline & Left hand & $0,973 \pm 0,032$ & $0,965 \pm 0,028$ & 0,240 \\
\hline & Mean & $0,978 \pm 0,027$ & $0,968 \pm 0,026$ & 0,175 \\
\hline
\end{tabular}




\section{Correlation between 2D:4D ratio and myopia degree}

A correlation test was done using Pearson and Spearman correlation tests. The data in the male group was normally distributed so the analysis used the Pearson correlation test. The Spearman correlation test was used in the female myopia sample group because the data was not normally distributed. We found no significant $(p>$ $0,05)$ correlation between $2 \mathrm{D}: 4 \mathrm{D}$ and myopia degree. The majority of the results in Table 4 was negative correlation with the correlation coefficient mostly being very weak $(r<0,2)$ whereas in the male group we got weak $(r: 0,2-0,399)$ and moderate correlation $(r: 0,4-0,599)$ between 2D:4D ratio and myopia degree.

Table 4. Correlation test result between 2D:4D ratio and myopia degree in left and right eye.

\begin{tabular}{|l|l|l|l|l|l|}
\hline Group & Object & Right eye & Left eye & & \\
\hline & & $\mathbf{r}$ & $\mathbf{p}$ & $\mathbf{r}$ & $\mathbf{p}$ \\
\hline $\begin{array}{l}\text { Total myopia sample } \\
(\mathbf{n}=\mathbf{4 7})^{\mathbf{b}}\end{array}$ & Right hand & 0,029 & 0,0847 & $-0,015$ & 0,918 \\
\hline & Left hand & $-0,067$ & 0,656 & $-0,002$ & 0,987 \\
\hline & Mean & $-0,031$ & 0,836 & $-0,007$ & 0,960 \\
\hline $\begin{array}{l}\text { Male } \\
(\mathbf{n}=\mathbf{7})^{\mathbf{a}}\end{array}$ & Right hand & $-0,262$ & 0,570 & $-0,535$ & 0,216 \\
\hline & Left hand & 0,522 & 0,229 & 0,301 & 0,512 \\
\hline & Mean & 0,183 & 0,695 & $-0,108$ & 0,818 \\
\hline Female $(\mathbf{n}=\mathbf{4 0})^{\mathbf{b}}$ & Right hand & $-0,034$ & 0,834 & $-0,101$ & 0,537 \\
\hline & Left hand & $-0,167$ & 0,303 & $-0,085$ & 0,609 \\
\hline & Mean & 0,135 & 0,465 & $-0,106$ & 0,575 \\
\hline
\end{tabular}

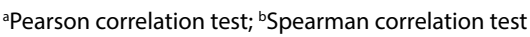

\section{Discussion}

BMI subjectivity arose as a problem in this study report because we got body height and weight data only from questionnaire screening. Therefore, BMI data in this research was expected not too valid because no standard measurement tool was used to count it. There is ongoing debate about the correlation between BMI and 2D:4D ratio. The first study in 2003 found that BMI had a positive correlation with 2D:4D ratio. ${ }^{23}$ Further study a few years later found that BMI was negatively correlated with 2D:4D ratio. ${ }^{24,25}$ Indeed, another report in 2014 showed that IMT has correlation to $2 \mathrm{D}: 4 \mathrm{D}$ in the age of $10-18$ years. ${ }^{26}$ Many studies also reported that IMT was not a biological predictor of prenatal androgen level which has effects on 2D:4D ratio. A better predictor of prenatal androgen level was waist to hip ratio and hand grip strength. ${ }^{27-29}$

The female respondents inadvertently outnumbered the male respondents, 
which was different from recent study (Table 1$){ }^{16}$ This was an ordinary result because in each cohort in 2012, 2013, and 2014, the females always outnumbered the males in a 3:1 ratio. Average myopia degree for right and left eye for myopic respondents summarized in the range of $S-(2,00 \pm 1,50)$ diopter, matching with previous studies. ${ }^{16,30}$

Theoretically, this research was directed to proof that 2D:4D ratio can be a good predictor for high grade myopia. Unfortunately, we only had one (2\%) respondent with a high myopia grade ( $>$ S -6 diopter); low-grade myopia respondents (up to S -3 diopter) were dominating (66\%). However, in the previous research conducted by Krishnakumar et al., ${ }^{16}$ there is no explanation about the number of each myopia grade as the limitation of respondents' myopia grade was only $\mathrm{S}-0,5$ diopter. This condition is one of the limitations in this study.

The fourth digit length tended to be higher than the second digit length (Table 2). This tendency happened because the androgen and estrogen receptor was higher in the fourth digit..$^{35}$ As to the impact, the 2D:4D ratio was always lower than one, even though females sometimes had a 2D:4D ratio of almost one or even higher than one. ${ }^{17,31}$ Ethnically, this research was conducted in Indonesia, which had Mongolian ethnic people so it can be compared with mean 2D:4D ratio of Mongolian. But, regrettably we could not make this comparison because no metaanalysis data exists about the 2D:4D ratio of mean Mongolian people..$^{32}$

The result of independent t-test in Table 3 revealed that there was no significant ( $p>0.05$ ) association between the 2D:4D ratio and myopia cases which was different from recent similar study reports which showed significantly different results in the female group. ${ }^{16}$ The insignificance may be because of worse measurement, ethnical difference, invalid BMI data, or menstrual cycle of women. Women dominated the number of respondents (82\%), but in this research menstrual cycles were not controlled. In women, the digit length was significantly $(p<0.05)$ different up to the period of menstrual cycle. ${ }^{33}$

The insignificance in Table 3 was followed by analysis results in Table 4 as there was no significant correlation ( $p>0.05$ ) between the $2 \mathrm{D}: 4 \mathrm{D}$ ratio and the myopia degree. Negative correlation dominated the result while in the male group there was a stronger correlation than in the other group. Negative correlation was observed because high prenatal androgen could have made higher fourth digit so $2 \mathrm{D}: 4 \mathrm{D}$ ratio was lower whereas high prenatal androgen could also elongate the axial eye length, which could increase the degree of myopia. ${ }^{16}$ Stronger correlation in the male group occurred because the androgen exposure was higher in males than in females.

Naturally, myopia is influenced by many factors which made it hard to correlate 2D:4D with myopia. Myopia has been well-established as a multifactorial disease with both a genetic and an environmental etiology. There are about 70 genetic loci that have been linked with myopia, such as $22 q 12$ locus and $11 p 13$ locus for MYP6 gene and MYP7 gene respectively, and many more. Familial aggregation studies have estimated sibling recurrence risks of common forms of refractive errors to range from 2 to 5.61 for myopia. Some systemic disorders are also associated with 
myopia, such as: Marfan syndrome, Cohen syndrome, Stickler syndrome, EhlersDanlos syndrome, Weill-Marchesani syndrome, homocystinuria, McCune-Albright syndrome, Kniest syndrome, Down syndrome, Prader-Willi syndrome, Noonan syndrome, Rubinstein-Taybi syndrome, Cornelia de Lange syndrome and fetal alcohol syndrome. ${ }^{36}$

There are several environmental factors implicated in myopia, including near work, light exposure, lack of physical activity, diet, higher level education, higher socioeconomic status, greater levels of educational attainment, and visually intensive occupations. Children with myopia spent more time studying, reading, and less time playing sports than children without myopia, even though the relationship between reading, near work activity is complex and remain poorly understood. Other environmental factors, such as exercising sports and time spent outdoors, have shown protective relationships which can reduce the risk of myopia. ${ }^{37}$ This research cannot cover the genetic and many environmental factors. Therefore, the input of genetic data and the other factors, as well as advance statistic methods such as regression models, are essential for the next study.

The research about 2D:4D and myopia has only been conducted twice so far. But, in this second research, because of the result and the limitation, we still cannot implement it as a predictor of a high myopia grade. Additional advance research still is required to confirm the results and to fix the limitation of previous research. This result also cannot be an additional proof for the 2D:4D ratio to be a potential prenatal androgen predictor.

Even while this study used computer-based measurement, which was the best measurement technique for measuring the 2D:4D ratio, ${ }^{21}$ there were several limitations other than we have discussed above that need to be fixed in the next research. Firstly, the BMI should be objectively and precisely measured because it could be a source of confounding factors and selection bias. Secondly, as we discussed before, the theory of an association between the 2D:4D ratio and myopia actually concerns specifically the axial type of myopia. Thirdly, this research involved not enough respondents and was lacking respondents with high grade myopia (S - 6 diopter or higher). So, in the next research, axial eye length should be the study target with more sophisticated ophthalmological tools to measure eye axial length, such as USG biometry. Also, we highly recommend that the next research will include a higher number of respondents and a higher number of respondents with high grade myopia.

\section{Conclusion}

There was no significant association between the second to fourth-digit ratio (2D:4D) with myopia cases in medical students of the Medical Faculty of Jenderal Soedirman University. 


\section{Acknowledgements}

We are grateful to all of the respondents for their voluntarily participation in this research. We are also grateful to Balai Kesehatan Mata Masyarakat (BKMM) Purwokerto for the refraction tests and Mr. Muflikhul Faizin, as the Refractionist in this research.

\section{References}

1. WHO. Appropriate body-mass index for Asian populations and its implications for policy and intervention strategies. Lancet 2004;363:157-163.

2. Foster PJ, Jiang Y. Epidemiology of Myopia. Eye 2014;28(2):202-208. doi:10.1038/eye.2013.280.

3. Paudel $P$, Ramson P, Naduvilath $T$, et al. Prevalence of Vision Impairment and Refractive Error in School Children in Ba Ria-Vung Tau province, Vietnam. Clin Exp Ophthalmol 2014;42(3):217-226. doi: $10.1111 /$ ceo.12273.

4. Sng CC, Lin X-Y, Gazzard G, et al. Peripheral Refraction and Refractive Error in Singapore Chinese Children. Invest Ophthalmol Vis Sci 2011;52(2):1181-1190. doi:10.1167/iovs.10-5601.

5. Tihayo I, Gunawan W, Suhardjo. Pertambahan Miopia pada Anak Sekolah Dasar Daerah Perkotaan dan Pedesaan di Daerah Istimewa Yogyakarta. Jurnal Oftalmologi Indonesia 2008;6(2):104-112.

6. Saw SM, Tong L, Chua WH, et al. Incidence and progression of myopia in Singaporean school children. Invest Ophthalmol Vis Sci 2005;46:51-57. doi:10.1167/iovs.04-0565.

7. Lai TY. Retinal Complications of High Myopia. Med Bull 2007;12(9):18-20.

8. Steidl SM. How Does Visual Acuity Change Over Time in Adults With High Myopia? J Ophthalmol 2006;90(5):524. doi:10.1136/bjo.2005.086421.

9. Rose K, Harper R, Tromans C, Waterman C, Goldberg D. Quality of Life in Myopia. J Ophtalmol 2000;84:1031-1034. doi: 10.1136/bjo.84.9.1031.

10. Takashima T, Yokoyama T, Futagami S, et al. The quality of life in patients with pathologic myopia. J Ophthalmol 2001;45(1):84-92.

11. Cao YN, Tang RH, Li RR, et al. A Retrospective Study on the Progression of Myopia in School-Age Children. Zhongguo Dang Dai Er Ke Za Zhi 2012;14(9):693-696.

12. Leong A, Rubin GS, Allan BDS. Quality of Life in High Myopia. Ophtalmology 2008;116 (2):275-280. doi:10.1136/bjo.84.9.1031.

13. Wagner H, Fink BA, Zadnik K. Sex and Gender-Based Differences in Healthy and Diseased Eyes. Optometry 2008;79:636-652. doi:10.1016/j.optm.2008.01.024.

14. Hornbeak DM, Young TL. Myopia Genetics: A Review of Current Research and Emerging Trends. Current Opinion in Ophthalmology 2009;20(5):356-362. doi: 10.1097/ICU.0b013e32832f8040.

15. Widodo A, Prilia T. Miopia Patologi. Jurnal Oftalmologi Indonesia 2007;5(1):19-26.

16. Krishnakumar M, Atheeshwar S, Chandrasekar MD. Myopia and Digit Ratio in Medical College Students. PLoS One 2014;9(2):1-4. doi: 10.1371/journal.pone.0089800

17. Moreira B, Matsushita R, Silva D, Da Silva S. Risk seeking behavior of preschool children in a gambling task. J Econ Psychol 2010;794-801.

18. Ciumas C, Lindén-Hirschberg A, Savic I. High fetal testosteron and sexually dimorphic cerebral networks in females. Cerebral Cortex 2009;19 (5):1164-1172. doi: 10.1093/cercor/bhn160.

19. Manning JT, Kilduff LP, Trivers R. Digit ratio (2D:4D) in Klinefelter's syndrome. Andrology 2013;1 (1): 94-99. doi: 10.1111/j.2047-2927.2012.00013.x.

20. Al-Salihi AR, Selman MO, Wasif HF. The Anthropometric Ratio of Index Finger to Ring Finger (2D:4D) Correlation with Some Seminal Fluid Analysis Parameters. The Iraqi Postgraduate Medical Journal 2011;10(2): 244-248.

21. Allaway HC, Bloski TG, Pierson RA, Lujan ME. Digit Ratios (2D:4D) Determined by ComputerAssisted Analysis are More Reliable than Those Using Physical Measurements, Photocopies, and Printed Scans. Am J Hum Biol 2009;21 (3): 365-370. doi: 10.1002/ajhb.20892.

22. Vermeersch $H, T^{\prime}$ Sjoen $G$, Kaufman JM, Vincke J, Van Houtte M. Testosterone, androgen receptor gene CAG repeat length, mood and behaviour in adolescent males. Eur J Endocrinol 2010;163(2):319-328. doi: 10.1530/EJE-10-0090. 
23. Fink B, Neave N, Manning JT. Second to fourth digit ratio, body mass index, waist-to-hip ratio, and waist-to-chest ratio: their relationships in heterosexual men and women. Ann Hum Biol 2003;30(6):728-738.

24. Van Dongen S. Second to fourth digit ratio in relation to age, BMI and life history in a population of young adults: a set of unexpected results. J Neg Res 2009;6:1-7.

25. Almasry SM, El Domiaty MA, Algaidi SA, Elbastawisy YM, Safwat MD. Index to ring digit ratio in Saudi Arabia at Almadinah Almonawarah province: a direct and indirect measurement study. J Anatomy 2011;218:202-208. doi: 10.1111/j.1469-7580.2010.01318.x.

26. Klimek M, Galbarczyk A, Nenko I, Alvarado LC, Jasienka G. Digit ratio (2D:4D) as an indicator of body size, testosterone concentration and number of children in human males. Ann Hum Biol 2014;41(6):518-523. doi: 10.3109/03014460.2014.902993

27. Hone LSE, McCullough ME. 2D:4D ratios predict hand grip strength (but not hand grip endurance) in men (but not in women). Evol Hum Behav 2012;33:780-789. doi:10.1016/j. evolhumbehav.2012.07.003

28. Zhao D, Li B, Yu K, Zheng L. Digit ratio (2D:4D) and handgrip strength in subjects of Han ethnicity: impact of sex and age. Am J Phys Anthropol 2012;149:266-271. doi:10.1002/ajpa.22130.

29. Fink B, Thanzami V, Seydel H, Manning JT. Digit ratio and handgrip strength in German and Mizos men: cross-cultural evidence for an organizing effect of prenatal testosterone on strength. Ann Hum Biol 2006;18:776-782. doi: 10.1016/j.evolhumbehav.2007.07.001

30. Gwiazda J, Deng L, Dias L, Marsh-Tootle W. Association of education and occupation with myopia in COMET parents. Optom Vis Sci 2011;88(9):1045-1053. doi:10.1097/OPX.0b013e31822171ad.

31. Honekopp J, Watson S. Meta-analysis of digit ratio 2D:4D shows greater sex difference in the right hand. Am J Hum Biol 2010;619-630. doi:10.1002/ajhb.21054

32. Galizzi MM, Nieboer J. Digit ratio (2D:4D) and altruism: evidence from a large, multi-ethnic sample. Front Behav Neurosci 2015;9:41. doi:10.3389/fnbeh.2015.00041

33. Mayhew T M, Gillam L, McDonald R, Ebling FJ. Human 2D (Index) and 4D (Ring) Digit Lengths: Their Variation and Relationships During the Menstrual Cycle. J Anat 2007;211(5): 630-638. doi: 10.1111/j.1469-7580.2007.00801.x.

34. Neyse L, Brañas-Garza P. Digit Ratio Measurement Guide. Kiel: Kiel Institute 2014.

35. Zheng Z, Cohn MJ. Developmental Basis of Sexually Dismorphic Digit Ratio. Proceedings of the National Academy of Sciences of the United States of America 2011;108(39):16289-16294. doi:10.1073/pnas.1108312108.

36. Mrugacz M, Rydzanicz M, Frajdenberg A, Podfigurna-Musielak M, Gajecka M. Myopia in systemic disorders. Klin Oczna 2009;111(1-3):84-88.

37. Mrugacz M. Role of the Genetic Factors in the Development of Myopia. In: Puiu M (ed.), Genetic Disorders, pp. 293-304. Rijeka, Croatia: Intech 2013. dx.doi.org/10.5772/52543 